\title{
Gilding Through the Ages
}

\author{
AN OUTLINE HISTORY OF THE \\ PROCESS IN THE OLD WORLD
}

\author{
Andrew Oddy \\ Research Laboratory, The British Museum, London, U.K.
}

In 1845, Sir Edward Thomason wrote in his memoirs (1) a description of a visit he had made in 1814 to certain artisans in Paris and he commented:

'I was surprised, however, at their secret of superior gilding of the time-pieces. I was admitted into one gilding establishment, and I found the medium was similar to ours, mercury; nevertheless the French did gild the large ornaments and figures of the chimneypiece clocks with one-half the gold we could at Birmingham, and produced a more even and finer colour'.

Much to his disgust, Thomason could not persuade the French workmen to tell him the secret of their superior technique, but it seems most likely that it lay either in the preparation of the metal surface for gilding or perhaps in the final cleaning and burnishing of the gilded surface. By the nineteenth century the so-called mercury-gilding process had remained essentially unchanged for over one and a half thousand years, but what Thomason did not know was that it was to be rendered obsolete almost before his memoirs were published, having been displaced by the introduction of galvanic gilding (2) in the years immediately following the first commercially viable patent for the process in 1840 .

The demise of mercury- or fire-gilding was not mourned, as the poisonous fumes emitted during the process were a health hazard not only to the workers but also to those living in the neighbourhood of a gilding workshop. Theophilus, writing in the twelfth century, already knew of the dangers inherent in the process (3), but concern over these did not find expression until the Society of Arts in England offered a prize in 1771, followed shortly by the Académie des Sciences in Paris, for an apparatus which would reduce the hazards of fire-gilding (4). However, it was

Fig. 1 Head of a silver statuette of a youth with a gilded headdress from the Treasure of the Oxus (around the fifth century B.C.). Note the seam around the edge of the headdress where the two sheets of gold foil have been burnished together not public concern but technological advance which brought an end to the use of amalgam for gilding.

\section{Gilding with Gold Foil}

Although fire-gilding had been in widespread use in Europe and Asia for at least 1500 years when it was displaced by electroplating, the origins of gilding that is, the application of a layer of gold to the surface of a less rare metal - go back at least 5000 years, to the beginning of the third millennium B.C. The British Museum has some silver nails from the site of Tell Brak in Northern Syria (5) which have had their heads gilded by wrapping gold foil over the silver.

This is, in fact, the earliest form of gilding and it depends not on a physical or chemical bond between the gold foil and the substrate, but merely on the mechanical effect of folding the foil over the edges of the underlying object. Mechanical gilding of this type can never have been very satisfactory, but there were two ways of improving it - the first was to apply an adhesive between the gold and the base metal, and the

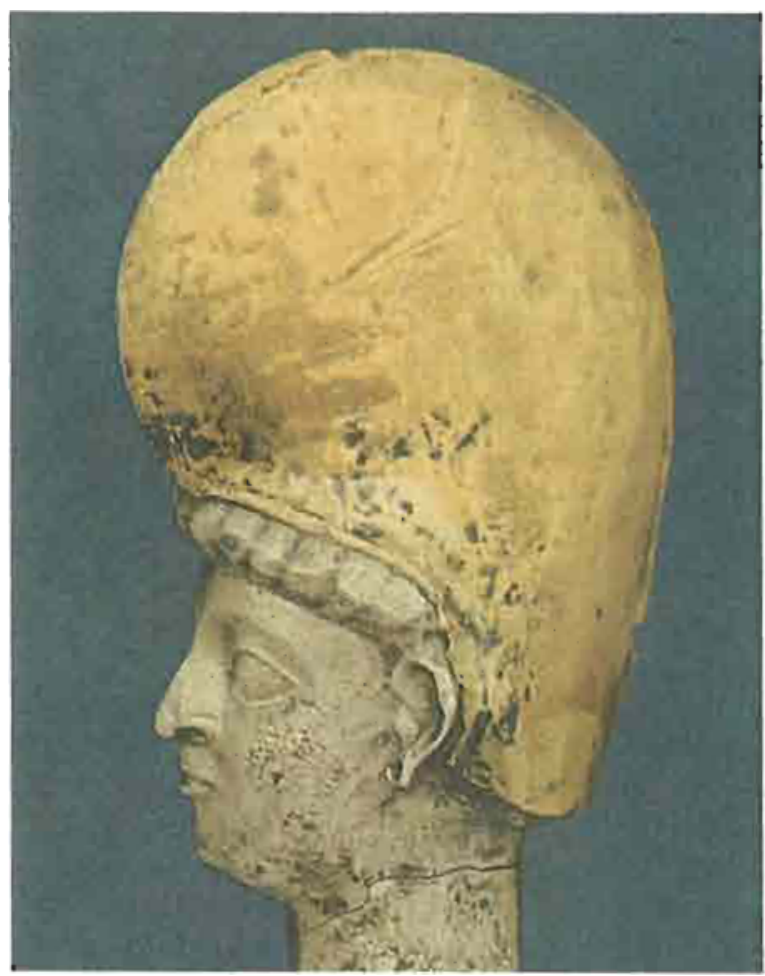




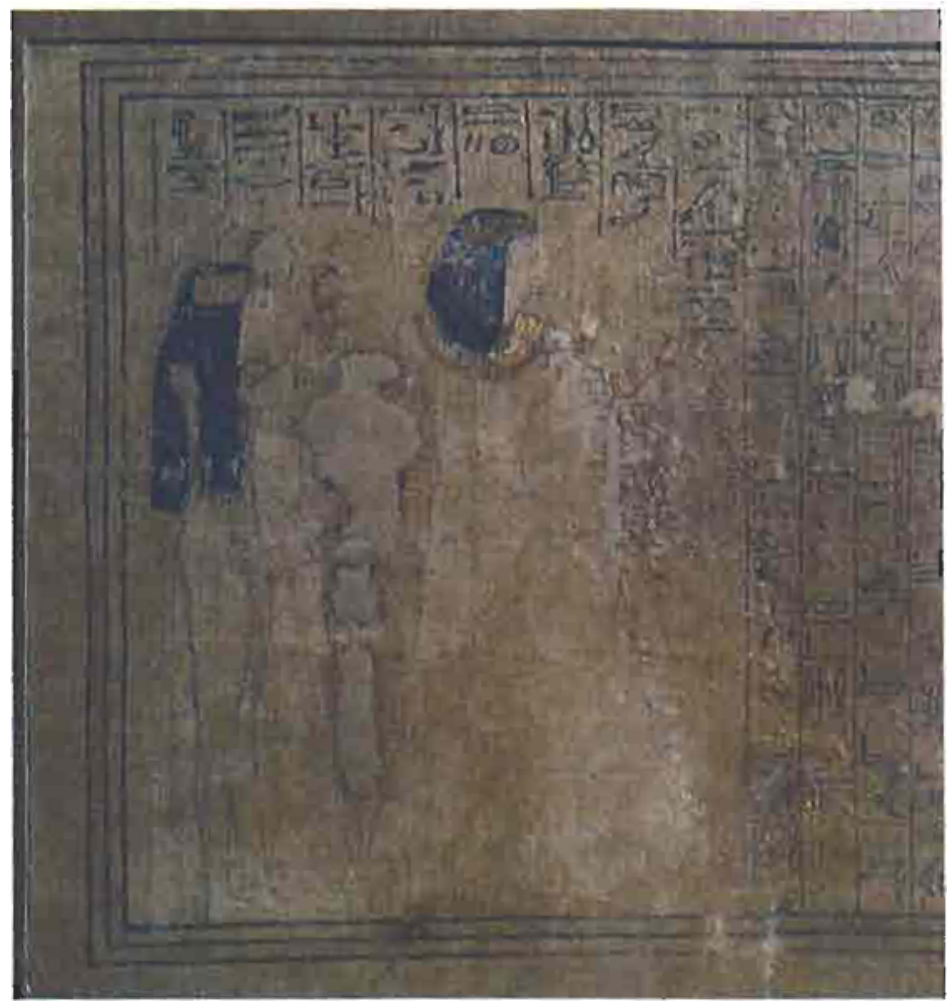

Fig. 2 Funerary papyrus of Neferronpet (fourteenth century B.C.) who is depicted with his wife Hunro and is described as 'ehief of the makers of thin gold'. This papyrus was originally decorated with gold leaf on the head-bands, collars, armlets and anklets of the two figures, but unfortunately most of this is now lost

second was to overlap the edges of the gold foil and then join them by burnishing. Used in one of these ways, foil gilding was durable and the technique persisted at least until the middle of the first millennium B.C. The Treasure of the Oxus, found in Central Asia in the middle of the nineteenth century and now in the British Museum, contains a number of examples of foil-gilded objects, but the finest is undoubtedly a silver statuette of a youth with a gilded headdress (6). The two sides of the headdress are covered with separate pieces of gold foil which overlap around the crest where they have been burnished together, and this is clearly visible in Figure 1.

\section{Gilding with Gold Leaf}

Apart from the above-mentioned improvements in securing the gold, the method of gilding with foil developed in two other ways. First, the foil became thinner and thinner until it should more correctly be called gold leaf and, secondly, a new method of attaching the gold foil was invented in which its edges were inserted into grooves cut in the surface of the substrate metal, rather than being wrapped round the edge of the latter.

The invention of gold leaf was impossible before the perfection of methods for the purification of gold, as only pure gold or gold-rich alloys free from certain impurities can be beaten out to produce the thinnest leaf. The introduction of gold refining is generally put at around 2000 B.C. in Mesopotamia (7), but it is quite possible that a better estimate could be made from a study of the dates of surviving objects which are covered in (traces of) gold leaf.

Gold beating to produce gold leaf is a specialized craft with a history going back at least as far as the New Kingdom in Egypt. In the British Museum there is a funerary papyrus of Neferronpet (8), of the fourteenth century B.C., who is described as 'chief of the makers of thin gold' (9) (Figure 2) and in the Cairo Museum is a stone relief from Giza in memory of Phthmay who bore the same title (10). Hammering out gold or electrum - a naturally-occurring alloy of gold and silver - is depicted on Egyptian tomb paintings as far back as the VIth Dynasty (around 2250 B.C.), but it is usually impossible to know whether it is the manufacture of foil or of leaf which is shown (see, for example, 11, 12). Another, more famous, relief of the Roman period is now preserved in the Vatican Museum (13). It shows a gold beater sitting at his anvil, who is described as aurifex brattiar(ius) (for an illustration see, for example, 14, 15).

Gold leaf is insufficiently strong to support its own mass and so new methods of attaching it to the substrate had to be developed. One obvious way was to use an adhesive and this method is still used today for the gilding of wood and stone, and for the decoration of leather bookbindings. Unfortunately, the animal or vegetable glues which were probably used have long since disappeared as the result of biological decay, and in many cases the gilding has been lost at 
the same time, to leave only traces of gold caught in folds and crevices of the design.

Besides being stuck directly to the base metal surface with an adhesive, gold can also be attached to fairly pure silver or copper by burnishing, provided that the substrate is scrupulously clean when the leaf is applied. The adhesion of the gold is enhanced by the application of heat to promote interdiffusion with the underlying metal, and this is probably the technique of gilding which was observed, without being positively identified, on a number of late Hellenistic and early Roman objects by Lins and Oddy (16). These authors were surprised to find that some silver objects from the second half of the first millennium B.C. and from the early first millennium A.D. had very thin and almost transparent coatings of gold on the surface, which resembled those obtained by the fire-gilding method, but which contained no trace of mercury. Furthermore, the gold was firmly bonded to the substrate and had no tendency to flake away, as is often the case when gold leaf has been stuck onto the surface with an adhesive.

When gold leaf is used to decorate wood or stone it is usual first to apply a ground of gesso (gypsum) or of a similar fine-grained material. This is then rubied down to give a very smooth surface before the adhesive and gold leaf are applied (17). Although this technique is not normally associated with metalworking, it has been used occasionally to gild bronze. Figure 3 illustrates a small Egyptian bronze figurine of a cobra (18) which is inlaid with lapis lazuli and gilded on top of a layer of finely ground dolomitic limestone. Presumably, this had first been mixed with an organic adhesive. Also in Figure 3 is a gilded copper leaf, from a tomb at Kameiros on the island of Rhodes (19), on which the ground between the base metal and the gilding consists of clay minerals (20). Both these objects date from about the middle of the first millennium B.C. and are so unusual that it is tempting to see them as the result of gilding operations actually carried out by workers in wood or stone rather than by the metalsmiths who made each of the objects.

\section{Gilding Large Bronze Sculpture}

Gilding with gold leaf was one of the developments to the foil technique and the other was the introduction of a new method of securing the edges of the sheets of foil. This involved cutting grooves in the base metal around the edge of the area to be gilded, fitting the edges of a sheet of gold foil into these grooves and then hammering the grooves closed again. An early example of this technique is a small Archaemenian silver bowl (21) which is decorated with rosettes, stepped pyramids and a procession of human figures (22).
This method of application of gold foil is important because it is the earliest one which seems to have been used for gilding larger objects. It was used on a late fifth century B.C. bronze head of a Nike (Victory), now exhibited in the Agora Museum in Athens (23), which has deep grooves round the edge of the face in which are to be found traces of gold foil. It was originally suggested that this method of gilding was chosen because the gold foil would only be put over the statue on festive occasions and then removed to prevent it being stolen (24). However, the recent discovery of fragments of a similarly gilded equestrian statue on the Agora (25), which has been identified as that of Demetrios Poliorketes and dated to the very end of the fourth century B.C. (26), shows that the gilding of statues with gold foil whose edges were trapped in grooves cut in the surface must probably be regarded as a normal technique among the Greeks for large sculpture which was designed to stand in the open air. Although examples of this technique of gilding are rare, it is mentioned by Pliny, who died just over 1900 years ago in the eruption of Vesuvius in 79 A.D., as the technique by which the Romans gilded an already ancient statue of Alexander the Great, which the Emperor Nero had brought from Greece (27).

Pliny is the earliest author to describe in any detail the methods of extraction and fabrication of metals and, although he was obviously not a craftsman, his 'Natural History' (28) is a mine of information for modern historians of technology. In fact, his work was written at a crucial period for the development of gilding technology because, besides the mention of foil gilding, Pliny describes the sticking of gold foil with an adhesive made from the white of an egg - a method still used today - or, alternatively, gilding with the aid of mercury.

When the surviving large gilded bronze statuary of the Roman period is examined, it is found to fall into two groups - either it has been cast in leaded bronze (typically 65 to 80 copper $/ 15$ to $30 \mathrm{lead} / 5$ to $10 \mathrm{per}$ cent tin) and has been gilded by sticking gold leaf to its surface with an organic adhesive or it has been cast in almost pure copper (over 95 per cent copper and

been decorated by the fire-gilding technique (29). No example of gold foil held in grooves seems to have been reported on surviving Roman statues.

Examples of the first group are fairly numerous in Italy and include the famous statue of the Emperor Marcus Aurelius which still stands on Capitol Hill in Rome, heads of some third century emperors in the Museum at Brescia and an equestrian group found at Cartoceta (30) and now in the Museum at Ancona. This last group of statues is extremely interesting because at first sight the gilding appears to form a 


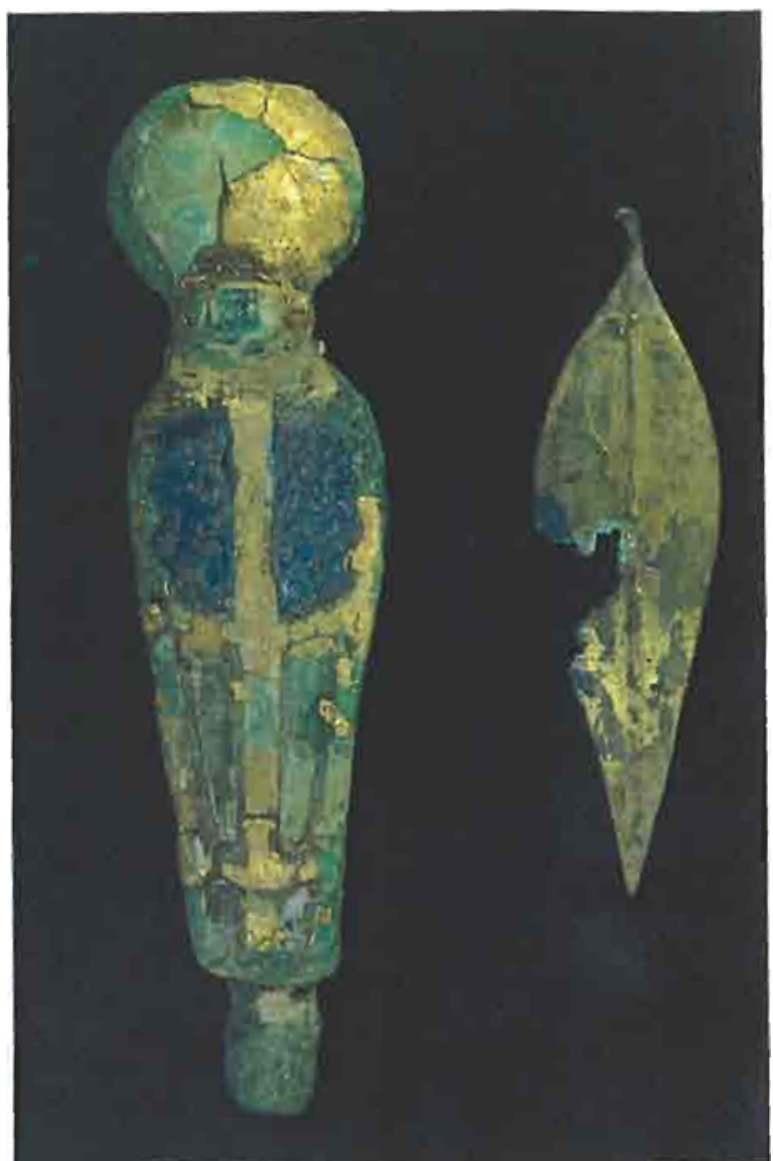

grid of criss-cross lines on the surface of the bronze (Figure 4). However, a careful inspection of the sculpture shows that these lines represent the overlap of the edges of adjacent gold leaves, where the double thickness of the gold has been less susceptible to loss by wear and weathering.

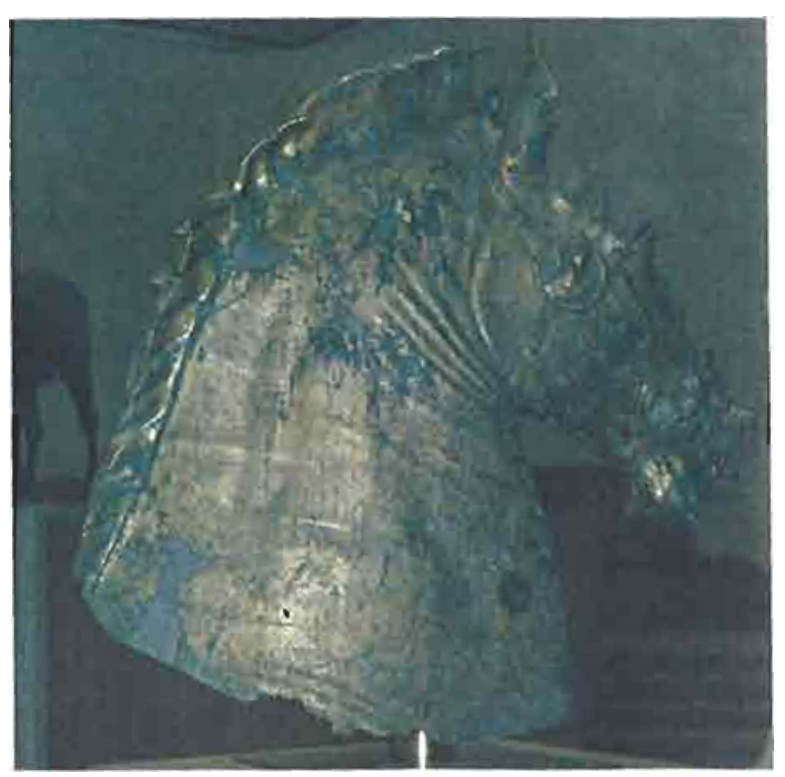

Fig. 3 Egyptian bronze figurine of a cobra which is inlaid with lapis lazuli and decorated with gold leaf applied on top of ground dolomitic limestone, and Greek copper leaf, perhaps from a funerary wreath, which has been leafgilded on top of a layer of clay minerals. Both objects date from about the middle of the first millennium B.C.

The reason why statues of the second group were made of almost pure copper, which is much more difficult to cast than leaded bronze, is that the presence of large amounts of lead in a bronze interferes with the process of mercury-gilding. The most important members of this group are a twice life-size statue of Hercules in the Vatican Museum, the great horses on the front of the Basilica of San Marco in Venice and some fragments of a gilded monument from the Roman fort of Richborough in Kent (31). The Hercules is thought to be third century A.D. in date and the fragments from Richborough must have come from a statue made between 100 and 300 A.D., and it therefore seems very probable that the San Marco horses are also late Roman (12).

If the demise of fire-gilding occurred in the midnineteenth century, when and where did it originate? Lins and Oddy have identified the technique on Chinese bronzes of about the third century B.C. (14) and Craddock has reported the presence of mercury in the gilding of some supposedly Hellenistic Greek bracelets and rings (32) which are, perhaps significantly, made of impure copper rather than bronze, but these are now almost all thought to be Roman in date. However, Pliny implies that the use of mercury for gilding was a very expensive process and his description has recently been interpreted as being that of a different technique in which mercury was used in a very thin coating on the substrate metal as an adhesive for gold leaf (33). There is little doubt from Pliny's description that the object was not subsequently heated, but that the excess mercury was allowed to evaporate away at room temperature.

Although gilding with mercury was a rare and costly process in the first century A.D. it had become the standard method of gilding by the third or fourth centuries and it remained unchallenged throughout the

Fig. 4 Head of a horse from a Roman statuary group found at Carloceta in Italy. It was cast in a leaded bronze and gilded by sticking squares of gold leaf onto the surface; a pattern of criss-cross lines, representing the edges of these squares, is faintly visible on the surface 
Dark Ages, the Medieval period and the Renaissance when its use is attested not only by the surviving gilded objects, but also by descriptions in a number of technological treatises ranging from the 'Mappae Clavicula' in the ninth century (34) to the works of Benvenuto Cellini in the sixteenth century (35).

\section{Acknowledgements}

My thanks are due to numerous colleagues in the British Museum who kindly loaned objects in their care for technological examination. In particular I am grateful to Messrs. T. G. H. James and W. V. Davies, of the Department of Egyptian Antiquities, for references to the manufacture of gold foil and leaf in ancient Egypt.

\section{References}

1 Sir Edward Thomason, 'Memoirs During Half a Century', Vol. 1, London, 1845, pp. 65-66

2 I.. B. Hunt, Gold Bull., 1973, 6, (1), 16-27

3 I. G. Hawthorne and C. S. Smith, 'On Divers Arts: The Treatise of 'Theophilus', The Chicago University Press, Chicago, 1963, p. 112; reprinted Dover, New York, 1979

4 G. Williams, Chem. Br., 1978, 14, 567-569

5 British Museum, Department of Western Asiatic Antiquities. Part of inventoly No. 127430

6 O. M. Dalton, 'The Treasure of the Oxus with other Examples of Early Metal-Work', 3rd edition, Trustees of the British Museum, London, 1964, Cat. No. 4

7 R. J. Forbes, 'Studies in Ancient Technology', Vol. VIII, 2nd edition, E. J. Brill, Leiden, 197

8 British Museum, Department of Egyptian Antiquities. Papyrus No. 9940

9 T. G. H. James, 7. Egypt. Archaeol, 1965, 51, 51-52

10 C. M. Zivie, Bull. Inst. Fr. Archéol. Orient., 1975, 75, especially pp. 304-306

11 P. Duell et al., 'The Mastaba of Mereruka', Univ. Chicago Orient. Inst. Publ., Vol. 31 , Chicago, 1938, pl. 30 and 33
$12 \mathrm{~W}$. Wreszinski, 'Atlas zur Altägyptischen Kulturgeschichte', Vol. III, J. C. Hinrichs, Leipzig, 1936, pl, 34

13 Vatican Museum, Roman Sculpture No. 753

14 W. A. Oddy et al., in 'The Horses of San Marco, Venice', The British Academy, London, 1979, pp. 182-187

15 A. Burford, 'Craftsmen in Greek and Roman Society', Thames and Hudson, London, 1972

16 P. A. Lins and W. A. Oddy, 7. Archaeol Sci, 1975, 2, 365-373

17 D. de Coetlogan, 'An Universal History of Arts and Sciences etc.', London, 1745, see entry under 'gilding' on p. 1200

18 British Museum, Department of Egyptian Antiquities. Inventory No. 63593

19 British Muscum, Department of Greek and Roman Antiquities. Registration No. 1861, 4-25, 2

20 W. A. Oddy et al., in 'Proceedings of the 18th International Symposium on Archaeometry and Archaeological Prospection, Bonn, March 1978', Archaeo-Physika, 1979, 10, 230-242

21 British Museum, Department of Western Asiatic Antiquities. Inventory No. 134740

22 W. A. Oddy, PACT Education, in press

23 T. L. Shear, Hesperia, 1933, 2, 514-541, especially 519-527

$24 \mathrm{H}$. A. Thompson, in 'Athenian Studies presented to William Scott Ferguson', Harvard Studies in Classical Philology, Suppl. Vol. I, Cambridge, MA., 1940, p. 198 ff.

25 T. L. Shear, Hesperia, 1973, 42, 121-179, especially pp. 165-168

26 C. Hauser, in 'Greece and Italy in the Classical World', edited by J. N. Coldstream and M. A. R. Colledge, Acta of the 11 th International Congress of Classical Archaeology, London, 1978 , p. 222

27 H. Rackham, 'Pliny: Natural History', Vol. 9, Loeb Classical Library, London, 1952 (reprinted 1968), p. 175

28 H. Rackham, 'Pliny: Natural History', Vol. 9, Loeb Classical Library, London, 1952 (reprinted 1968)

29 W. A. Oddy and P. T. Craddock, unpublished results

30 S. Stucchi, Boll. Arte, 1960, 45, 7-44

31 At present in the care of the Department of the Environment (Ancient Monuments Laboratory) in London

32 P. T. Craddock, 7 . Archaeol. Sci., 1977, 4, 103-123

33 O. Vittori, Gold Bull., 1979, 12, (1), 35-39

34 C. S. Smith and I. G. Hawthorne, Trans. Am, Philos, Soc, $1974,64,1-128$

35 C. R. Ashbee, 'The Treatises of Benvenuto Cellini on Goldsmithing and Sculpture', Dover, New York, 1967

\section{A First Century Model Ship}

A fascinating little votive model of a lage sailing boat, found in 1891 at Broighter in County Derry in the north of Ireland and preserved in the National Museum of Ireland in Dublin, not only shows some early craftsmanship in gold but also establishes that shipbuilding by the Celts was well developed before the advent of the Romans. The model, about $20 \mathrm{~cm}$ in length, dates from the early first century A.D. and represents a ship of about $16 \mathrm{~m}$ in length. It is double ended, square rigged, and has thwarts for nine rowers on each side with a single steering oar on the port side. It was made

Photograph by courtesy of the National Muscum of Ireland, Dublin from one sheet of rather pale gold containing some silver, and represents either a wooden boat or one having a framework covered with hide.

L.B.H.

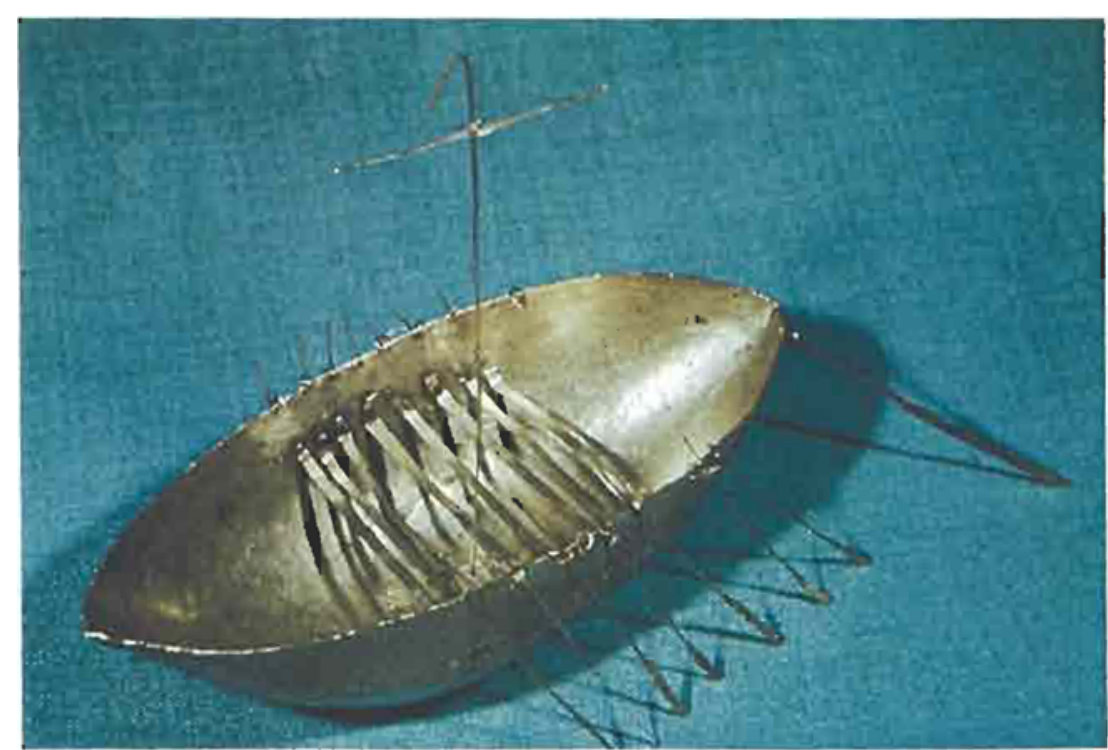

